\title{
ANIMALS IN PEOPLE'S MIND AND IN THE LANGUAGE OF FOLKLORE
}

\section{Henni Ilomäki}

\section{WHAT IS PEOPLE'S ATTITUDE TO ANIMALS BASED ON?}

According to the researchers of taxonomy cognitive perception is not due to intellectual needs, because the process is unconscious (Berlin 1992: 8). Can the classification of animals thus be independent of cultural context? Animals appear in Finnish folklore and they also belong to contemporary everyday life. Are the attitudes of today's people any different from those of earlier generations?

In oral tradition there is no extensive classification of animals. Traces of classification may, however, be detected in the 44th Rune of the Finnish epic poem Kalevala, Wäinämöinen's Playing

Every wild beast of the woodland

Crouched upon its paws to listen [---].

Birds came flying through the air

Settling down on twig and sampling [---],

And the fish of every species

Crowded up against the shore [---]

Even worms beneath the earth

Crept and crawled up to the surface.

Although this division follows the classification of modern biology, it is irrelevant to treat it as essential from the aspect of cognitive classification in oral tradition.

Various spells have been used to regulate the daily routine and turning points of human life as well as the material and mental well-being and relationships between people. For example, social relationships were defined in the seer's incantation, healing spells were used to maintain health, hunting and cattle spells to guarantee means of livelihood. In the following I examine the names of animals mentioned in spells published in "Old Poems of the Finnish People" [Suomen Kansan Vanhat Runot; SKVR] as indicators of re- 
lationship between people and animals. Information on modern attitudes comes from research literature and magazines for pet keepers. In addition, I refer to issues published in the newspapers in spring 1995.

\section{THE ROLE OF SPELLS IN HUNTING}

In primitive hunting culture the hunter worked alone and treated its prey like an individual. The relationship between the hunter and the animal was a personal one and it was based on mutual respect. It was presumed that the game surrendered voluntarily (Ilomäki 1986). Differently from domestic animals, wild animals retained their independence until death. Prey animals belonged to the forest, a world that remained outside the control of people. In order to meet a prey animal the hunter had to strive physically (e.g. Jochelson 1926) or to lure it to a certain place (Fardon 1990: 194). Hunting spells describe not only animals but also the ideal hunting landscape. Communication with the forest was important and the correctness of address was a precondition to success (Ilomäki 1986).

In hunting spells the prey animal could be called juoni (tricky), metsän vilja (forest fruit), jalan neljän juokseva, viijen vinttoileva (runner on four feet, roller on five), rannan kiertäjä (roamer on the coast), someron sorottaja (gravel treader) or rahakarva (money-fur), villakuontalo (bunch of wool), karvapalli (fur ball), kultaturkki (golden fur) or veronahka (tax fur).

The essential criteria about the game are running and the fur. The way of moving has been used as a descriptive element in spells read when fixing traps:

Yhen paan siivin kiitävälle, One I put for those flying on wings, toisen jalon juokseville,

kolmannen maassa mataville another for those running on feet, third for those crawling on the ground.

When specifying fowl as the expected prey, the criterion is the plumage: tuft of feathers (höyhentuppelo), bluewing (sinisiippana). Terms specifying the fowl species may be found, but even four-legged prey 
animals may be called by denotative bird-names. [Similarly, in earlier Estonian the word 'lind' (bird) could mean game: linnunahkne kasukas (birdskin coat) could be made of the fur of a fox or another fur animal; in a newer folk song the rabbit calls itself vaene lind (poor bird) etc - Comment by Kristi Salve.] The names for the squirrel that was hunted for fur, are luring: oravainen, oikiainen (squirrel, the straight one), metsän valkea vasikka (white calf of the forest), kävyn syöjä kännervöini (cone eater), metsän kissa kirmijäinen (forest puss), puun kuningas (king of the tree), metsän kukka (forest flower). The rabbit was not hunted for fur; it was trapped like fowl, and spells were cast to get it into the trap, using pejorative names: jänis jäppä, juppaniska (rabbit the crooked neck), vinttura, pyöräsilmä (cross-eyed), hiien kanttura (old bat of the devil).

Consequently, animals are addressed both by neutral general terms and by names referring to species. The latter are usually not denotative - they are euphemisms with either endearing or pejorative nuance. Denotative names may indicate another animal (dog, calf, ewe of the forest). The taxonomic component is not associated with qualities of species, but with the interest of the hunter i.e. the expected prey. The names describe both the animal and the hunter's attitude to it. In principle slaughtering an animal was contradictory to the amity between man and animal (Serpell 1986: 140-142). Therefore the illusion that death was based on agreement required ritualisation (Jochelson 1975: 146-147) and affected the choice of words.

\section{ANIMALS AS A MEANS OF MYTHICAL DEFINITION}

Healing spells often start with invocation of the reciter's courage. The verses define his/her power and means. Sometimes they also refer to animals:

mull on kourat kontiolta, I got a bear's paws, veren juojalta vekarat, limbs from the bloodsucker, linnulta lihan pitimet, meat pinches from the bird, havukalta haarottimet. claws from the hawk.

A mie olen suuri susi, muut riuvukse revokse

I am a big wolf, others all are rotten foxes. 
Having identified the disease the seer was stronger than it, and he/ she made it leave the patient. Several animals are represented as the removers of the disease or as the destination the illness is taken to:

Hauki sun syvälle viepi, lohi luovolle vetäpi.

The pike takes you to the depths, the salmon draws you upon an islet.

Kissa kirjava vetävi, kukko musta kiijättävi.

Let the spotty pussycat pull,

Hirven paksuhun lihahan petran paksun palliohon the black cock scare away.

Into the thick flesh of the moose, to the thick midriff of the reindeer.

The dog may be the one who carries the driven-off disease, but it can also act as an assistant to the bewitcher: kylän kirojen syöjä (eater of village curses). The disease may be transferred to or its causes located to places connected with the breeding and death of animals:

Mis on korppi koinattuna, Where the raven was conceived, musta lintu muokattuna. the black bird grown.

Siell on hirvet hirsipuussa, There are moose on gallows tree, oksissa metän otukset. wild animals on its branches.

These expressions refer to the concept of shaman's animal assistants and their mythical interpretation (Siikala 1992: 187-189, 199). The emphasis of a feature in this kind of context turns affective, and the interpretation is based on anomaly. In hunting spells the use of euphemisms is a preventive measure. In healing spells instead, calling a beast by name entails control of the problem - or a purposeful violation of taboo.

So, the context determines the attitude of the bewitcher to the animal: the prey is addressed respectfully, whereas in healing spells the animal is humiliated and reproached. Words obtain a different meaning in poetry:

kanna korppi huoliani, raven, carry my care, musta lintu murhettani black bird, my worry 
This is a reserved variant of exorcism. The choice of words in spells is based on the presumed magic power of the spoken word and the intention of hunting.

\section{HOW THE MODERN PERSON PERCEIVES ANIMALS}

The animal is often defined as the negation of the human being (Ingold 1988: 3-6). The human being belongs to culture, the animal belongs to nature - either completely or partially like domestic animals do. Humans do not rule over wild animals, although reading spells aim at it. Modern people's knowledge is based on biological classification, though actually there is no universally acknowledged standpoint - the attitude has to be described in a different way.

One criterion of attitude is the profit that man makes from an animal. People always wanted to use animals. The most multifaceted efficiency occurs between the nomad and his animals (Digard 1990: 75 . The closer to the modern time and to the economic objectives of household management, the more essential this factor becomes. The central element in the man-animal relationship is still the fact that man causes death to animals. The most common reason for killing is food. In the hunting culture death could initially be interpreted as being based on agreement, but the death of a domestic animal is the decision of people and only people, because of the latter's undetached nature and hierarchic superiority (Ingold 1994: 16; Serpell \& Paul 1994: 132). Compared to the hunter, the "guilt" of the herdsman is manifold: at the end of a long-term relationship, which was based on care, he kills the animal, his source of economic profit and not an individual (Serpell 1986: 5, 48-54, 151; Clutton-Brock 1994: 31). Stock-farming products are not related in the consciousness of a modern-day consumer with the animals from which they were made (cf Singer 1991: 100-101).

In no culture man would use all animals for food: eating trotters, circus animals or pets, for example, is regarded impossible. An entire industry is involved with pets: in England a billion pounds a year is spent on feeding them. Relationships with pets are sometimes called a compensation for deficient relationships between 
people. Are any people unselfish in their relationship to animals? The whale-savers at least?

Nutritional restrictions have been explained in different ways. Today vegetarians often refer to the ecological load of meat products or the suffering caused to animals by intensive cattle breeding (Singer 1991: 151-176). People no more hunt for food or reflect on their relationship with the game. The focus is rather on the ritual aspect of hunting, or on the possibility of spending time in nature. Actually hunting for meat is considered aesthetically more tolerable from the point of animal rights than intensive cattle breeding (Tengvall 1992: 25). The same applies for the opposition of amateur and industrial fishing.

Attitude to animals can also be observed from the point of accompanying emotions. Even nomads "cared" for animals, although ruling was the main trend in the relationships. Pets are kept for the sake of emotions and their feelings are presumed to be satisfied. Contrary to the game, pets do not bring profit, it is inconceivable to eat them. The reason for this is evidently their status in the human society: they live together with people, they have a name and, in addition to that, moral values and qualities may be attached to them (Patoluoto 1989: 107-108). The relationship between the pet and its owner is undoubtedly important, it makes the latter feel necessary (Serpell 1986: 19-33). Pet keeping is supported by an extensive industry and lively publishing activities. There are chat-rooms on the Internet for pet keepers as well as for those interested in birds or butterflies. Magazines for both amateur hunters and fishermen are published, and every year special handbooks come out - from weapon manuals to cookery books and instructions how to make flies for fly-fishing.

Likewise, the relationship between the man and the animal acquires different forms on the grounds of familiarity/unfamiliarity. The reality of contemporary people may include contacts with wild animals in circuses, zoos and animal parks, as well as with laboratory animals, doves or parasites. The personal relationship between tamed animals and their keeper develops similarly to the one between pets and their keepers. The favourites of an ornithologist, however, stay further away: bird watching and counting does not necessarily include meeting them. Hunting clothes, binoculars, ar- 
tificial flies for fishermen have a central role in these relationships. Inevitably the urban citizen's relationship to nature becomes materialised (Ahonen 1987: 400), therefore live animals may even be experienced as terrifying (Midgley 1988: 37).

The most attractive qualities of pets are considered to be their anthropomorphic features as well as the possibility for non-verbal communication (Serpell 1986: 61-67, 100-133). Animals acting like people get a new role in comic strips and animated cartoons. When marginalised to such show business roles, anthropomorphised animals do not retain their original animal qualities (Coy 1988; Tapper 1988: 56). In extreme cases real animals become anomalous in comparison with the imaginary ones; city children may know the duck from Disneyland fantasy world better than the domestic fowl of the same name. True enough, in this way also the positive ideological information may be channelled (Tambiah 1969: 457).

\section{RELATIONSHIPS AND CLASSES}

Both in the spells and in modern Finnish materials animals are treated on the basis of interpretations created by people's cultural contexts. The animal figures in hunting spells are defined by the hunter according to his expectations. They are product units, like animals in the sphere of intensive agriculture that has caused passionate dispute. Animals associated with hobbies demand expenses (Serpell 1986: 11-122), but provide pleasure.

Differences in opinions arise from various backgrounds. Even the status problem has its role - like it is the case with the healer practising verbal magic. Culture is segmented by social groups and different circles are not familiar with another's reality. Hunting spells were the tradition of men, hunting and fishing are still men's hobbies, at the same time pets are often kept in families with children. Only part of the animal-related knowledge of modern people is empirical: the terminology familiar to aquarium owners is not extended to horse riders or fox breeders. Animal concepts do not require ethnobiological classification, they are explained on the basis of cultural meanings. There are both in-group meanings and universal ones both in oral tradition and in modern thinking and these 
differentiate attitudes rather than animals. The terms describe both animals and people's relationship with them.

\section{References}

Ahonen, Pirkko-Liisa 1987. Metsä elämäntavassa. - Reunala, Aarne \& Virtanen, Pekka (eds.). Metsä suomalaisten elämässä $=$ The forest as a Finnish cultural entity. Silva Fennica 12: 4. Helsinki: Finnish Society of Forest Science.

Berlin, Brent 1992. Ethnobiological classification: Principles of categorization of plants and animals in traditional societies. Princeton: Princeton University Press.

Clutton-Brock, Juliet 1994. The unnatural world: Behavioral aspects of humans and animals in the process of domestication. - Manning, Audrey \& Serpell, James (eds.). Animals and human society: Changing perspectives. London \& New York: Routledge, pp. 36-38.

Coy, Jeannie 1988. Animals' attitudes to people. - Ingold, Tim (ed.). What is an animal? London: Unwin Hyman, pp. 77-83.

Digard, Jean-Pierre 1990. L'homme et les animaux domestiques: Anthropologie d'une passion. Le Temps des sciences. Paris: Fayard.

Fardon, Richard 1990. Between God, the dead and the wild: Chamba interpretation of the ritual and religion. International African library, 8. Edinburgh. Edinburgh University Press for the International African Institute.

Ilomäki, Henni 1986. Eläiten nimittämien ja luontosuhde. Petojen roolit pohjois- ja rajakarjalaisissa kalevalamittaisissa runoissa. Lis. työ. Helsinki: Helsingin yliopisto.

Ingold, Tim 1988. The animal in the study of humanity. - Ingold, Tim (ed.). What is an animal? London: Unwin Hyman, pp. 84-99.

Ingold, Tim 1994. From trust to domination: An alternative history of human-animal relations. - Manning, Audrey \& Serpell, James (eds.). Animals and human society: Changing perspectives. London \& New York: Routledge, pp. 1-22.

Jochelson, Valdemar 1975. The Yukaghir and the yukaghirized Tungus. American Museum of Natural History, New York, Memoirs, Vol. 13, pt. 13. The Jesup North Pacific Expedition. Publications, Vol. 9, Ch. 1-3. New York: AMS Press.

Midgley, Mary 1988. Beasts, brutes and monsters. - Tim Ingold (ed.). What is an animal? London: Unwin Hyman, pp. 35-46.

Patoluoto, Ilkka 1989. Hyöty, rakkaus ja sivistys suhteinamme eläimiin. Häyry, Heta \& Tengvall, Helena \& Vilkka, Leena (eds.). Eläin ihmisten maailmassa. Preesens-sarja. Helsinki: Gaudeamus, pp. 108-116.

Serpell, James 1986. In the company of animals: A study of humananimal realtionships. Oxford \& New York: B. Blackwell. 
Serpell, James \& Paul, Elizabeth 1994. Pets and the development of positive attitudes to animals. - Manning, Audrey \& Serpell, James (eds.). Animals and human society: Changing perspectives. London \& New York: Routledge, pp. 127-144.

Siikala, Anna-Leena 1992. Suomalainen samanismi: Mielikuvien historiaa. Suomalaisen kirjallisuuden seuran toimituksia 565. Helsinki: Suomalaisen kirjallisuuden seura.

Singer, Peter 1991. Oikeutta eläimille. Transl. to finnish and compl. by Helena Tengvall. Helsinki: Werner Söderström.

SKVR = Salminen Väinö (ed.) 1948. Suomen kansan vanhat runot XIV: Uudenmaan runot. Suomalaisen kirjallisuuden seuran toimituksia 151. Helsinki: Suomalaisen kirjallisuuden seura.

Tambiah, Stanley J. 1969. Animals are good to think and good to prohibit. - Ethnology 8 (October), 4, pp. 423-459.

Tapper, Richard 1988. Animality, humanity, morality, society. - Ingold, Tim (ed.). What is an animal? London: Unwin Hyman, pp. 41-62.

Tengvall, Helena 1993. Eläinten puolesta: Eläinten ystävän käsikirja. Helsinki: Werner Söderström. 